\title{
THE INTEGRATION MODELS OF PROCUREMENT MANAGEMENT OF HYBRID PROJECTS IN DEVELOPMENT OF PROJECT-ORIENTED ENTERPRISES
}

The aspects of resource provision of project implementation in development of project-oriented organizations and its positioning on domestic and international markets are studied in the article. It significantly affects not only the results of projects` research, but also the sustenance and development of such organizations. For realization of stated tasks, the authors proposed several conceptual models that allow to combine the processes of project management and operational processes of the company and on this basis to create hybrid projects for efficient procurement of product components and resources for project portfolio.

Keywords: nanobiotechnologies, project-oriented enterprises, procurement, project management model.

Introduction. Recently, with the influence of crisis that unfolded in the economy, more and more attention is paid to the study of the role of the State in macroeconomic regulation processes [1]. Thus, the focus is on the problems of regulation of the financial sector, in particular around the measures and instruments that are used by regulatory agencies to ensure support for banking system stability. Also, in our opinion, the role of the State is significantly increasing in conditions of economic crisis through the use of this instrument of economic regulation as procurement, including Public procurement [2], which can quite significantly affect the supply and demand for socially important goods, works and services both in the country, and within individual regions. This is especially true for project activities, in particular in realization of international investment programs. Accomplishment of these programs, based on project approach is extremely important in the present circumstances. It should be noted that in such programs the processes of project procurements constitute almost $80-100 \%$ of project tasks performed according the specific rules. These tasks are complex, limited in time and have assessed effectiveness with a focus on achievement of a certain results [3]. In addition, these project procurements have to be combined with procurements, that provide operation activity of customer`s company and have the character of public or commercial purchases. In this regard, the study of the role and importance of integration approaches to implementation of all types of procurement processes for the project and operating activities of the companies in the economy of the State, peculiarities of development of hybrid integrated procurement system and its components are very important today.

Solving this problem will provide the combination of resource procurement packets for production and project activities, reduce the number of procurement procedures, reduce costs, enlarge contracts and procurement contracts, consider the image component in determination of the best participant of procurement procedures. This may increase the efficiency of procurement processes and improve results of both project and operational activities.

Analysis of research and publications and definition of unsolved aspects of the problem. It should be noted that national scientific literature doesn't pay considerable attention to this problem. Concerning public procurements, the main published papers on this subject rather have legal character or form of analytical reports, prepared by the Ministry of Economic Development and Trade [4] and other regulatory agencies.

In recent time, a number of national scientists make research on the issue of public procurements from the point of view of scientific and theoretical grounds, among them I. Burakovsky, N. Tkachenko, Y. Umantsiv, A. Ovsyanyuk, A. Minyaylo, V. Smyrychynskiy.

In addition, a number of Russian scientists are involved in research of this direction, among them: E. Kovalev, M. Koryttseva and I. Pogosov, A. Sokolowski, R. Arykbayeva and others [5-9]. These studies are based on the functioning of the public procurement system.

Regarding project procurements, we follow the requirements of international standards for project management [10, p.355] and also research results obtained by professors S.D. Bushuev [11, p.111], V.A. Rach [12, p.126] and V.V. Morozov [3, 13].

Analysis of informational resources points out an accurate separation of operational and project activities. Basing on practical experience of project procurements in terms of POE, it can be said, that this activity in regard of procurements on professional level, seldom can be joined with obtention of hybrid (joint) result.

In recent time there have appeared the researches of hybrid project management, reflected in following articles $[14,15]$.

Regarding given the above, we can say that the systems of procurement are closely related to both production (operating) and project activity (in the case of project-oriented business), and thus appears a scientificpractical problem to give grounds of functioning of management systems which would take into account the features of the operating system and project management [14].

However, today no systematic research of this problem is found.

The purpose of the article is to form a holistic system vision of integrated procurement management for project-oriented companies and organizations, international projects and programs that are currently implemented in Ukraine and abroad. 
Results and discussion. The analysis of realization of international projects and development programs in Ukraine, that are funded by international financial institutions, indicates that one of funding part of such projects is a mandatory part of the State [5]. This leads to the need to implement the requirements of modern legal framework for the implementation of State procurement on the one hand, and the requirements of international organizations that provide funding for State development programs, on the other. It should be noted, that these requirements are always different from each other, they reflect the various aspects of monitoring of funds usage and are aimed at different areas of organization that is currently implementing the project or program.

Thus, for the implementation of development programs at the expense of the International Bank for Reconstruction and Development (EBRD) created Directorates development programs (or Directorates), which is primarily project management offices (PMO), have their own operations activity, also provide the resource requirements of customers projects (Ministry). Of course, such activities, in turn, should be provided in certain types and amounts of resources.

Of course, such activity should be provided in certain types and amounts of resources. Thus, for example, the following program of Ukraine, in which one of the authors took a direct part "Equal Access to Quality Education in Ukraine" (100 mln. USD) for the Ministry of Education and Science of Ukraine, where have been held more than 100 procurement procedures on different procedures for IBRD standards and requirements of national legislation; "Preparation of the Second Adjustment Loan" (2.6 mln. USD) for the Ministry of Economy and European integration in Ukraine with a total of 50 tender packages; "Termination of use of substances that deplete the ozone layer" (24 mln. USD) for the Ministry of Environmental Protection of Ukraine with a total of 30 tender packages (Figure 1): "The model of operational procurement management of different functional departments" - model " distribution".

The research and analysis of this procurement scheme indicates that today, along with performance of project management standards` requirements, including project procurement, there is a need for project-based approach to management of operational activities. Integration (somehow) of these two types of procurement systems leads to hybrid procurement projects and emerges a problem of their management.

Hybrid project procurement is a typical project activity limited in available resources and time, which results unique goals in the form of products or rendered services to meet the specified requirements for quality.

Management problems in operating activities of project-oriented enterprises (POE) have been the subject of many publications, including [6-8]. According to the competence of logistics in ensuring the POE with materials, to implement a systematic approach to material supply management within the delivery service must be taken certain steps.

To ensure the POE with material supply, it is necessary to solve the problem: "What to buy"; "How to buy"; "On what terms to purchase." Also, the following work must be done: "To sign the contract"; "To control the contract"; "To arrange delivery"; "To organize storage (Figure 2: model "optima").

The task "Where to buy" and "On what terms to purchase" are solved by Procurement Directorate. At the same time earlier mentioned works on supply are performed: contract conclusions and control of their implementation. As a result, the function of material flow control and raw material control is divided between two different services and its effective implementation becomes difficult.

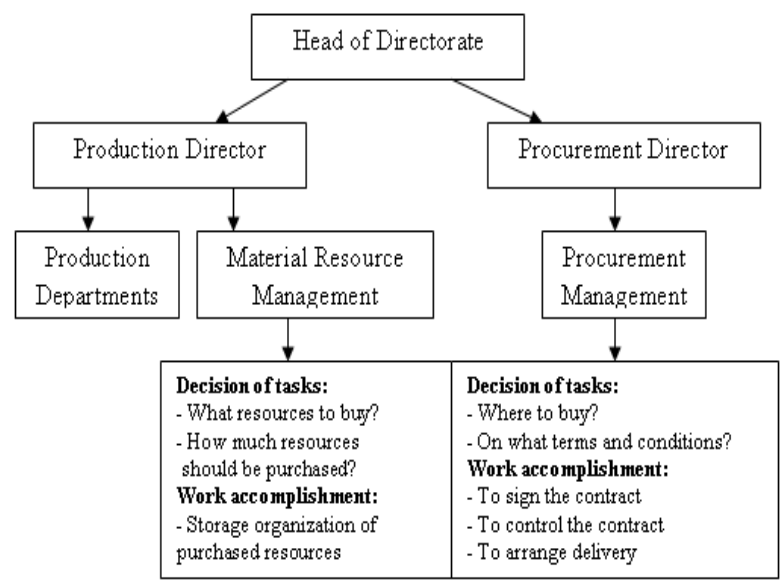

Fig. 1 - The model of operational procurement management of different functional departments

Another option, shown in Figure 2, presumes the concentration of all functions of procurements and supply in one hand. This structure creates wide opportunities for logistic optimization of material flows at the stage of resource procurement.

However, moving to the analysis of procurement activity within international programs for project-oriented enterprises (directorates of PMO) should also be taken into account the basic project activity of the company, as it was underlined in the beginning of the article, aimed to implement a complex project and to receive targeted results. A requirement list to such activities, considering project procurements, is defined in many publications, for example [3, p.297; 4, p.355; 9, p.588].

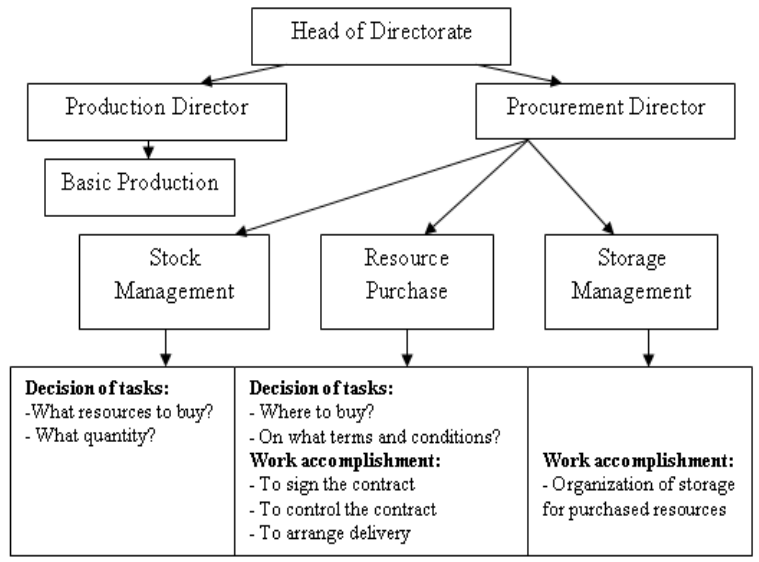

Fig. 2 - The model of operational procurements 
First of all, it should be noted that project procurement is characterized by a certain horizontal integration in management, because, at least in project procurement planning, should be used many results of previous in other knowledge areas of project management. Among these results (documents) [3, 10], in particular, are "Project Management Plan" from the Integration project management component (group of project management processes - 4.2), "Requirements description" from the component Content project management (requirement collection process - 5.2 ), "Risk identification description" from the component Risk project management (the process of risk identification -11.2), and so on.

In general, for procurement project management eight incoming documents (Fig. 3), the presence of which is determined by certain standards and ensures a transfer to planning of project procurement procedures in order to increase their effectiveness [9] (model "integro") are used. In order to ensure timely documentation flow and approval, an effective work of department of material supply of POE must be ensured (Fig. 3).

As it is seen from the Figure 3, two integration contours are dotted lined: vertical - proposed in this article and horizontal, which is based on the international standards of project management.

Thus, making project procurements, one must be focused on hybrid projects. They combine processes and procedures on public procurements on the bases of state legal framework, according to annual plan of procurements and project procurements, that are implemented according to the project needs in certain resources and approved complex project plan schedule. Such task of automation becomes a more relevant when considered the project portfolio or development programs for project-oriented companies. However, in international projects, that are implemented by international financial organizations such as the IBRD and concluded contracts are also on the bases of project procurement procedures, where project-organizational structure of project management is implemented.

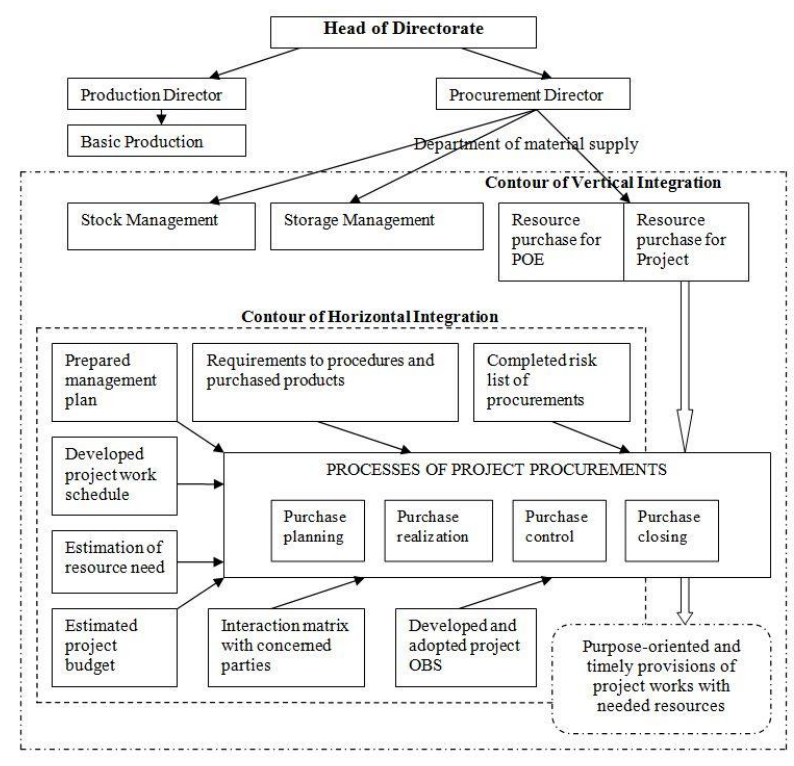

Fig. 3 - The model of integrated procurement in hybrid projects
The need to create a computer procurement control system for hybrid and international projects is predetermined by several reasons:

1. The researched categories of projects are characterized by implementation of usually large number of micro-projects in various regions across the country. This project structure requires the involvement of a considerable number of people of various specializations, including specialists in procurements. It is necessary to provide their access to project procurement management in computer information system.

2. In this situation, the exchange of information between different departments and professionals working in the project and that provide procurement processes and contracts and also exercise the functions of control and planning, will bring certain difficulties if the computer information system of project management is not implemented.

3. The cycle of initiation, preparation and implementation of each procurement procedure - is a set of activities performed during a long time. Different specialists are involved to this time-consuming procedure, such as: engineers, economists, management of organization, procurement specialists and others. Each of this expert works with a certain group of procurement processes. For organization and information processing, which further goes in operation of various experts on different stages of the procurement procedures, it is necessary to create a central database.

4. The financing of mentioned projects is usually carried out by three or more sources, such as a loan or grant from the World Bank; the contribution of the government of the State that is implementing the project; the contribution of communities, that are implementing micro-projects; various public and private foundations and donor organizations may also support the project. Conditions and procedures for disbursement and implementation costs for all of these funding sources may differ. All this makes it virtually impossible to make financial transactions in the project without creating a computerized financial accounting system, that must be closely integrated into procurement system.

5. All organizations, that are involved in the preparation and implementation of procurements are interested in getting different information about project progress and results. This reporting should cover all aspects of the project. Creation and coordination of such reports is greatly simplified if there is created a computer system of procurement management.

\section{Conclusions.}

As a result of research, there were found similar types of activities in organization and conduction of procurement procedures both for operating activity of POE and project implementation.

The integration of two types of procurement activities for the POE is possible through a combination of group of processes - stock management, warehouse management, operational management and project procurement. 
The considered integration of procurements results in the emergence of a new essence - a hybrid project procurements, which management is significantly different.

There were discovered two types of integration of procurements for international projects and programs vertical and horizontal integration. The developed conceptual approaches and models form a complete vision system of procurement in complex international projects.

Prospects for further research in this direction. The results of presented research and models give the opportunity to conduct their further analysis and proceed to the formation of mathematical and algorithmic models, the research of which, in its turn, will provide an opportunity to explore a broader class of enterprises that use hybrid scheme of project management and to generate practical recommendations for the specific formation of such management systems.

References: 1. Zakon Ukrainy "Pro derzhavni zakupivli" [Law Of Ukraine "On Public Procurementv"] from July 1, 2014, № 1234-VII from May 06, 2014 [in Ukrainian]. 2. Morozov, V. V. (2008). Osoblyvosti upravlinnya mizhnarodnymy proektamy u sotsial'niy sferi [Pecularities of international project management in social sector] Upravlinnya prohramamy orhanizatsiynoho rozvytku u konkurentnomu otochenni. IV mizhnarodnaia konferentsia "Upravlinnya proektamy $u$ rozvytku suspil'stva" - Program management of organizational development in competative environment. "Project management in social development" IV International conference. (pp 93-95). Kyiv : KNUBA [in Ukrainian]. 3. Morozov, V. V. (2003). Osnovy zakupivel' tovariv, robit ta posluh $v$ proektakh [Bases for project procurement of materials, works and services]. Kyiv: Takson, 744 [in Ukrainian]. 4. Say Ministerstva ekonomichnoho rozvytku i torhivli. Derzhavni zakupivli. [Site of Ministry of Economic Development and Trade of Ukraine. State procurements]. me.gov.ua. Retrieted from http://www.me.gov.ua/Tags/DocumentsByTag?lang=uk-

UA\&tag=DerzhavniZakupivli [in Ukrainian]. 5. Koryttsev, M. A (2006). Kvazirynok hosudarstvennykh zakupok: varianty orhanizatsyy i poteri effektivnosti [Kvasi-market of state procurements : organization variants and efficient losses]. Ekonomicheskyi vestnik Rostovskoho hosudarstvennoho unyversyteta - Economical Bulletin of Rostov State University, 4 (2), 112-118. [in Russian]. 6. Pogosov, I. A. \& Sokolovskaya, E. A. (2009). Dohody $i$ raskhody sektora gosudarstvennogo upravleniya v period krizisa 2008-2010 gg. (Ocenka finansovo-kreditnoj politiki gosudarstva v period krizisa) [Revenues and expenses of state management during crises period of 2008-2010 year Assessment of finance-credit state policy in the period of crisis]. Moscow : Institut ehkonomiki RAN, 44 [in Russian]. 7. Morozov, V. V.
(2009). Praktychni aspekty rozrobky konkursnoyi dokumentatsiyi na zakupivlyu robit [Practical aspects of development of tender documentation for work procurement]. Informatsiyno-analitychnyy visnyk "Derzhavni zakupivli Ukrayiny". - Information-analitical bulletin "Ukraine State Procurements", 8(62), 29-35 [in Ukrainian] 8. Tkachenko, N. B. (2007). Upravlinnya derzhavnymy zakupivlyamy [State Procurement Management]. Kyiv: "Knyha", 296 [in Ukrainian]. 9. Smyrychyns'kyy, V. (2009). Lohistyka kontraktnykh vidnosyn na rynku derzhavnykh zakupivel' [Contract relationship logistics on the market of state procurements]. Informatsiyno-analitychnyy visnyk "Derzhavni zakupivli Ukrayiny". - Information-analitical bulletin "Ukraine State Procurements", 8(62), 20-22 [in Ukrainian]. 10. A Guide to the project management body of knowledge (PMBOK guide 5th editon). (2013). USA: PMI Standards Committee, 589. 11. Bushuev, S. D., YAroshenko, F. A., \& Tanaka, H. (2012). Upravlenie innovacionnymi proektami i programmami na osnove sistemy znanij P2M [Innovation Project and Programe Management Basing on P2M Knowledge System]. Kyiv: "Sammit-Kniga", 272 [in Russian]. 12. Rach, V. A., Rossoshans'ka, O. V., \& Medvedyeva, O. M. (2010). Upravlinnya proektamy: praktychni aspekty realizatsiyi stratehiy rehional'noho rozvytku [Project management: practical aspects for realization of strategy of regional development]. Kyiv : "K.I.S.", 276 [in Ukrainian]. 13. Morozov, V. V. (2015). Procurement management in development projects of the process approach to decision-making. "Science in the modern information society $V ", 3$, (pp. 158-161). USA, North Charleston: Scientific Publishing Center "Academic. 14. Sidorchuk, L. L., Sidorchuk, A. V., \& Ratushnyj, R. T. (2015). Metodologicheskie osnovy upravleniya gibridnymi proektami [Metodological bases for hybride project management]. Visnyk NTU "HPI" - Bulletin NTU "KhPI", 1 (1110), 66-71 [in Russian]. 15. Beal, A The 3 types of hybrid projects, and how they affect the business analyst's work. modernanalyst.com. Retrieved from http://www.modernanalyst.com/Resources /Articles/ tabid/115/articleType/ArticleView/articleId/2228/The-3-types-of-hybridprojects-and-how-they-affect-the-businessanalystswork.aspx\#sthash.Z3 UzZRBx.dpuf. 16. Projects of International Research and Development Bank. vsemirnyjbank.org. Retrieved from http://www.vsemirnyjbank.org/projects/search?lang=ru\&_ search Term $=\&$ countrycode_exact=UA. 17. Burkov, V. N. (1996). Economical mechanisms of production management. Moscow, 32. 18. Bushueva, N. S. (2007). Models and methods of proactive program management of organizational development. Kyiv, 270. 19. Bushuev, S. D. (2007). Proactive program management of organizational development. Moscow, 4 (12), 270-282. 20. Morozov, V. V., Chumachenko, I. V., Dotsenko, N. V., \& Cherednichenko, A. M. (2014). Project management: planning processes of project works. Kyiv, 673. 21. Morozov, V. V. (2010). Elevation of procurement effectiveness in projects on the basis of management of concerned parties. VII International conference "Project Management in Society Development" (pp. 140-141). Kyiv.

Received 30.11.2015

\section{Відомості про авторів / Сведения об авторах / About the Authors}

Морозов Віктор Володимирович - кандидат технічних наук, професор, завідувач кафедри технологій управління факультету інформаційних технологій Київського національного університету імені Тараса Шевченка, м. Київ, тел.: (050) 358-09-50; e-mail: knumvv@ gmail.com.

Morozov Viktor Volodymyrovych - Candidate of Technical Sciences, Professor, Head of Department for Technology Management, Faculty of Information Technologies of Taras Shevchenko National University, Kyiv, tel.: (050) 358-09-50; e-mail: knumvv@gmail.com.

Любима Юлія Олександрівна - аспірант Університету економіки та права КРОК, начальник відділу наукового співробітництва із зарубіжними партнерами та стандартизації УкрНДІНанобіотехнологій, м. Київ; тел.: (050) 287-03-71; e-mail: Alary7 @ukr.net.

Liubyma Iuliia Oleksandrivna - PhD candidate of "KROK" University, Head of Department for Scientific Collaboration with Foreign Partners and Standardization, Kyiv; tel.: (050) 287-03-71; e-mail: Alary7@ukr.net. 